\title{
Problematika Pembelajaran Dalam Jaringan (Daring) pada Mata Pelajaran Pendidikan Agama Islam di SMA Negeri 4 Pariaman
}

\author{
Mulia Guswanti ${ }^{1}$, Rengga Satria ${ }^{2}$ \\ Jurusan Ilmu Agama Islam, Fakultas Ilmu Sosial, Universitas Negeri Padang, Indonesia ${ }^{1,2}$ \\ muliaguswanti6@gmail.com ${ }^{1}$, renggasatria@fis.unp.ac.id ${ }^{2}$
}

\begin{abstract}
Abstrak
Penelitian ini bertujuan untuk mengetahui bagaimana problematika yang dihadapi pendidik dan peserta didik dalam pembelajaran daring pada mata pelajaran Pendidikan Agama Islam; dan mendeskripsikan upaya yang dilakukan dalam mengatasi problematika pembelajaran daring pada mata pelajaran Pendidikan Agama Islam; selanjutnya untuk menganalisis bagaimana hasil yang dicapai dalam upaya mengatasi permasalahan pembelajaran daring pada mata pelajaran Pendidikan Agama Islam. Metode yang digunakan dalam penelitian ini ialah penelitian kualitatif dengan pendekatan deskriptif, sumber data diambil kepada tiga belas informan melalui wawancara langsung yang terdiri dari kepala sekolah, pendidik dan peserta didik. Untuk memperkuat data penelitian penulis juga mengambil data melalui observasi dan dokumentasi. Seluruh data wawancara dianalisis dengan cara pengumpulan, reduksi, penyajian dan diakhiri dengan pengambilan kesimpulan. Secara keseluruhan hasil penelitian ini menunjukkan bahwa, pertama, pada aspek problematika terdapat empat problematika yang dihadapi dalam pembelajaran daring yaitu penguasaan teknologi yang masih rendah dikalangan pendidik, peserta didik yang kurang motivasi dalam belajar, keterbatasan sarana dan prasarana, dan kurang efektifnya pembelajaran daring. Kedua, pada aspek upaya dalam mengatasi problematika pembelajaran daring sekolah melakukan bimbingan teknis dan penyediaan mentor untuk pendidik yang tidak memahami teknologi, pendidik memberikan motivasi dan melakukan bimbingan belajar, sekolah menyediakan sarana dan prasarana seperti penyediaan kuota internet dan labor komputer sekolah bagi yang tidak memiliki smartphone dan pendidik berusaha menciptakan pembelajaran daring yang efektif dengan mengoptimalkan pembelajaran. Ketiga, pada aspek hasil yang dicapai setelah dilakukan upaya dalam mengatasi problematika pembelajaran daring yaitu sarana prasarana peserta didik menjadi memadai, motivasi belajar yang meningkat dan menciptakan pendidik yang terbiasa dengan teknologi, keefektifan belajar yang meningkat.
\end{abstract}

Kata Kunci : Problematika, Pembelajaran Daring, Pendidikan Agama Islam

\begin{abstract}
This study aims to find out how the problems faced by educators and students in online learning in Islamic Religious Education subjects; and describe the efforts made in overcoming the problems of online learning in Islamic Religious Education subjects; then to analyze how the results achieved in an effort to overcome the problems of online learning in Islamic Religious Education subjects. The method used in this study is a qualitative research with a descriptive approach, data sources were taken to thirteen informants through direct interviews consisting of principals, educators and students. To strengthen the research data, the author also takes data through observation and documentation. All interview data were analyzed by collecting, reducing, presenting and ending with conclusion. Overall the results of this study indicate that, first, in the problematic aspect there are four problems faced in online learning, namely the low mastery of technology among educators, students who lack motivation in learning, limited facilities and infrastructure, and the ineffectiveness of online learning. Second, in the aspect of efforts to overcome the problems of online learning, schools provide technical guidance and provide mentors for educators who do not understand technology, educators provide motivation and conduct tutoring, schools provide facilities and infrastructure such as providing internet quotas and school computer labor for those who do not have smartphones.
\end{abstract}


and educators strive to create effective online learning by optimizing learning. Third, in the aspect of the results achieved after efforts have been made to overcome the problems of online learning, namely the infrastructure of students is adequate, learning motivation is increased and creating educators who are familiar with technology, learning effectiveness is increased.

Keywords: Problems, Online Learning, Islamic Religious Education

\section{Pendahuluan}

Pendidikan yaitu usaha yang dilakukan oleh individu secara terencana untuk membimbing individu lain agar dapat berkembang menjadi manusia mandiri, bertanggungjawab, berilmu, dan berakhlak mulia (Inanna, 2018). Di Indonesia saat ini muncul masalah akibat adanya wabah penyakit Covid-19, yang menyebabkan banyak kegiatan yang harus dihentikan dan dialihkan menjadiWork From Home (WFH), begitu juga dengan kegiatan di bidang pendidikan. Kegiatan di bidang pendidikan pada saat ini dilakukan dengan sistem daring. Pembelajaran daring merupakan salah satu strategi pembelajaran online yang dilakukan melalui jaringan online atau internet untuk mempertemukan antara pendidik dan peserta didik (Mustofa, 2019).

Salah satu mata pelajaran yang diajarkan secara daring yaitu Pendidikan Agama Islam. Pendidikan Agama Islam bertujuan untuk mempersiapkan agar peserta didik bisa mengenal, memahami, menghayati, hingga mengimani ajaran agama Islam, disertai dengan tuntunan untuk saling menghormati pemeluk agama lain untuk menciptakan kerukunan umat beragama sehingga terwujud kesatuan dan persatuan bangsa (Kurikulum PAI, 2002). Pelaksanaan pembelajaran daring di dalamnya terdapat beragam problematika yang dihadapi oleh pendidik dan peserta didik,salah satunya di SMA Negeri 4 Pariaman. Sekolah ini terletak di Jalan Siti Manggopoh, Naras Hilir, Pariaman Utara, Kota Pariaman, Sumatera Barat. Semua mata pelajaran disekolah ini diajarkan melalui sistem daring.

Pelaksanaan pembelajaran Pendidikan Agama Islam yang dilakukan secara daring ada beberapa masalah yang dirasakan oleh pendidik dan peserta didik. Permasalahan yang terjadi di antaranya tidak semua materi pembelajaran yang bisa diajarkan secara daring, ada keterbatasan untuk tanya jawab, tidak semua peserta didik yang miliki HP android, keterbatasan jaringan dan kuota internet, pendidik yang kurang memahami teknologi dan rendahnya minat peserta didik dalam mengikuti pelajaran. Pada kondisi saat sekarang ini Pendidikan Agama Islam memiliki peran yang sangat penting bagi peserta didik saat menghadapi pandemi Covid-19 ini. Pada dasarnya pembelajaran Pendidikan Agama Islam merupakan salah satu cara yang bertujuan untuk pengembangan kepribadian yang berjalan selamanya, baik formal atau nonformal, dan untuk menjadikan pribadi yang lebih berkualitas. Pribadi yang sesuai dengan aspekaspek spiritual, moral, sosial, intelektual, sehat jasmani, rohaninya sesuai petunjuk ajaran Islam serta mampu menerapkan iman, pengetahuan, dan perbuatan sesuai ajaran Islam dalam kehidupan sehari-hari demi mendapatkan kesenangan dunia serta akhirat merupakan pribadi yang berkualitas dalam Islam.

Uraian tersebut di atasbisa dipahami bahwa pembelajaran daring merupakan solusi alternatif dalam pelaksanaan pembelajaran di masa pandemi covid-19, meskipun memunculkan sejumlah permasalahan dalam penerapannya baik bagi pendidik dan 
peserta didik. Maka dalam kajian penelitian ini diajukan sebuah pertanyaan permasalahan penelitian, yaitu bagaimana problematika pembelajaran daring yang diterapkan di masa pandemi covid-19, bagaimana solusi pemecahannya dan bagaimana hasil yang dicapai? Hasil penelitian ini diharapkan dapat menjadi bahan informasi dan rujukan dalam mengambil kebijakan dalam melaksanakan pembelajaran daring, baik bagi pendidik dan peserta didik.

\section{Tinjauan Pustaka}

Problematika merupakan ketidaksesuaian antara harapan dengan kenyataan yang membutuhkan suatu pemecahan atau penyelesaian (Muhith, 2018). Problematika juga bisa diartikan sebagai hal yang menghalangi tercapainya suatu tujuan. Untuk mencapai tujuan yang telah ditetapkan dibutuhkan solusi atau pemecahan terhadap masalah yang dihadapi. Problematika yang dibahas pada penelitian ini yaitu problematika pembelajaran daring pada mata pelajaran Pendidikan Agama Islam. Pembelajaran merupakan kegiatan yang dilakukan pendidik dalam meransang, membimbing, mengarahkan dan mendorong serta mengorganisir proses belajar peserta didik agar mereka memiliki pengetahuan dan kebudayaan serta dengan proses pembelajaran mereka mampu mengembangkan pengetahuan yang diperoleh sesuai dengan bentuk dan tujuan pendidikan (Halid, dkk, 2018), sedangkan daring memiliki arti dalam jaringan.

Merujuk dari pendapat diatas Sigit Priatmoko (2020) mengatakan bahwa pembelajaran daring ialah sebuah sistem yang bisa memfasilitasi peserta didik belajar lebih luas, lebih banyak, dan lebih bervariasi, melalui fasilitas yang disediakan oleh sistem, jadi peserta didik bisa belajar kapan dan dimana saja tanpa terbatas jarak, ruang, dan waktu. Pelaksanaan pembelajaran daring diperlukan dukungan perangkat mobile seperti smartphone atau telepon android, laptop, komputer, tablet, yang digunakan untuk mengakses informasi kapan saja dan di mana saja (Meda \& Janner, 2020). Kesimpulannya pada masa pandemi covid-19 ini memberikan begitu banyak pelajaran, tidak hanya tentang upaya memutuskan rantai penularannya, tetapi juga bagaimana peserta didik tetap bisa belajar dan bagaimana sekolah-sekolah bereaksi memanfaatkan teknologi dalam proses belajar mengajar.

Ditjen GTK (2016) berpendapat bahwa pembelajaran daring memiliki beberapa karakteristik diantaranya: pertama, peserta didik harus mampu untuk membangun dan menciptakan pengetahuan secara mandiri (constructivism). Kedua, peserta didik dituntut untuk berkolaborasi dengan peserta didik lain agar dapat membangun dan memecahkan masalah secara bersama-sama (sosial constructivism). Ketiga, menciptakan komunitas pelajar (comunity of learners) yang inklusif. Keempat, memanfaatkan website yang bisa diakses melalui internet, pembelajaran berbasis komputer, kelas virtual dan kelas digital. Kelima, adanya interaktivitas, kemandirian, aksesibilitas, dan pengayaan.

Berdasarkan karakteristik diatas dalam proses pembelajaran daring digunakan media dengan memanfaatkan jaringan internet dalam pelaksanaannya. Rini \& Maulana (2020) berpendapat bahwa pembelajaran daring bisa menggunakan beberapa aplikasi sebagai media pembelajaran, yaitu Google Classroom, Zoom Video Conference, WhatsApp Group, dan E-learning. 
Pembelajaran daring yang dimaksud dalam penelitian ini yaitu pada mata pelajaran Pendidikan Agama Islam, dimana Pendidikan Agama Islam ialah upaya untuk mengajarkan nilai-nilai agama Islam agar menjadi way of life (pandangan dan sikap hidup) peserta didik. Menurut Saputra (2014) Pendidikan Agama Islam merupakan upaya yang dilakukan secara sadar dalam mentaati ketentuan Allah SWT sebagai pedoman dan dasar bagi peserta didik supaya mereka berpengetahuan keagamaan dalam menjalankan ketentuan-ketentuan Allah. Pendidikan Islam mempunyai tujuan yang sama dengan pendidikan pada umumnya, yaitu membentuk pribadi manusia melalui proses yang panjang, yang hasilnya tidak dapat diketahui dengan segera (Ramayulis, 2010).

Tujuan dari pendidikan Islam pendidik dan peserta didik dicapai dengan keharusan memahami dan menyadari betul apa yang ingin dicapai dalam proses pendidikan.Ramayulis \& Nizar (2009) menyebutkan ada beberapa prinsip dalam pendidikan Islam diantaranya: pertama, prinsip pendidikan Islam merupakan implikasi dari karakteristik manusia, yaitu antara manusia dengan makhluk lainnya dibedakan oleh fitrah, kesatuan roh, jasad, dan kebebasan berkehendak. Kedua, prinsip pendidikan Islam sebagai pendidikan integral, dimana tidak dibenarkan adanya dikotomi pendidikan yaitu antara Pendidikan Agama dengan pendidikan sains. Ketiga, pendidikan Islam merupakan pendidikan yang seimbang, maksudnya yaitu adanya keseimbangan antara kehidupan dunia dan akhirat, individu dengan masyarakat, dan keseimbangan badan dan roh. Keempat, bersifat universal, bahwa dalam pendidikan Islam harus meliputi seluruh aspek kehidupan manusia dan tidak boleh hanya memberi penekanan kepada salah satu aspek saja dan meninggalkan aspek yang lainnya. Kelima, bersifat dinamis, dimana pendidikan Islam selalu berupaya untuk memperbaharui diri dan berkembang sesuai dengan perkembangan zaman.

Prinsip berarti asas, kebenaran yang dijadikan pokok dasar orang-orang untuk berpikir, bertindak dan sebagainnya (Kamus Besar Bahasa Indonesia, 2007). Jadi, berbicara tentang prinsip pembelajaran Pendidikan Agama Islam berarti berbicara tentang asas atau pokok dasar yang mendasari pelaksanaan pembelajaran Pendidikan Agama Islam.

\section{Metode Penelitian}

Metode yang digunakan dalam penelitian ini ialah penelitian kualitatif dengan menggunakan pendekatan deskriptif. Wibowo (2011) menyatakan bahwa metode deskriptif yaitu metode penelitian yang berusaha untuk memaparkan dan mendefenisikan objek dengan apa adanya, bukan berupa angka melainkan berupa ungkapan bahasa melalui defenisi yang tepat dan sistematis. Sumber data penelitian diambil kepada tiga belas informan dengan teknk purposive sampling melalui wawancara langsung yang terdiri dari kepala sekolah, tiga orang pendidik pada mata pelajaran Pendidikan Agama Islam dan sembilan orang peserta didik. Untuk memperkuat data penelitian penulis juga mengambil data melalui observasi kepada pendidik yang sedang mengajar pembelajaran melalui e-learning dan peserta didik yang sedang mengikuti pembelajaran secara daring. Selanjutnya sebagai bukti penulis menjalankan penelitian terkait dengan isu dan permasalahan yang di kaji maka penulis 
juga mengabadikan seluruh kegiatan yang dilakukan seperti wawancara langsung dengan informan dan proses pembelajaran daring menggunakan e-learning moodle. Seluruh data wawancara dianalisis dengan cara pengumpulan, reduksi, penyajian dan diakhiri dengan pengambilan kesimpulan. Setelah data dikumpulkan, data tersebut dianalisis secara kualitatif dengan model Miles and Huberman. Menurut Miles dan Huberman (Sugiyono, 2007), aktivitas dalam analisis data kualitatif dilakukan secara interaktif dan terus menerus sampai tuntas yang digambarkan dalam empat langkah. Empat langkah tersebut meliputi data collecting (pengumpulan data), data reduction (reduksi data), data display (penyajian data), dan conclusion drawing/verification (penarikan kesimpulan dan verifikasi). Ketepatan dan kebenaran data yang sudah berhasil digali, dikumpulkan dan dicatat dalam kegiatan penelitian haarus dipastikan dengan baik. Untuk menguji kredibilitas dan pengecekan data, maka diperlukan teknik pemeriksaan. Terdapat beberapa teknik yang digunakan dalam pengecekan keabsahan temuan di antarannya yaitu perpanjangan keikutsertaan, ketekunan pengamatan, dan triangulasi.

\section{Hasil dan Pembahasan}

Pelaksanaan kegiatan proses belajar mengajar secara daring di lingkungan SMA Negeri 4 Pariaman ditemukan beberapa problematika yang secara langsung atau tidak langsung dapat menghambat proses pelaksanaan pembelajaran pada mata pelajaran Pendidikan Agama Islam. Problematika itu tidak hanya pada peserta didik melainkan terdapat pula pada pendidik sebagai subjek dalam proses pendidikan. Berdasarkan hasil wawancara penulis dengan Kepala Sekolah yaitu Ibu Desi dan pendidik pada mata pelajaran Pendidikan Agama Islam Bapak Mardison, Bapak Pendi dan Ibu Liza (wawancara 22 sampai dengan 27 Maret 2021), penulis mendapatkan bahwa ada 2 problematika yang berasal dari pendidik, yaitu:

Pertama, pengusaan teknologi pendidik yang masih rendah, ini sesuai dengan pendapat bapak Mardison hasil wawancara pada tanggal 23 Maret 2021, beliau mengatakan:"Dalam pelaksaan kegiatan pembelajaran secara daring tidak semua pendidik terampil dalam menggunakan teknologi internet dan media sosial, apalagi yang sudah berumur seperti bapak, sudah susah untuk mempelajari tentang teknologi tersebut, karena banyak sekali cara-cara yang harus dipahami".

Asmuni (2020) berpendapat bahwa tidak semua guru mampu mengoperasikan komputer atau gadget untuk mendukung kegiatan pembalajaran, baik dalam tatap muka langsung, terlebih lagi dalam pembelajaran daring, memang ada sebagian guru mampu mengoprasikan komputer, tetapi dalam hal pengopresian terbatas, mereka tidak mampu mengakses lebih jauh yang berkaitan dengan jaringan internet, menggunakan berbagai aplikasi pembelajaran, membuat media atau video pembalajaran sendiri dan sebagainya. Pendidik dipaksa atau diharuskan untuk dapat belajar IT lebih jauh yang kadang kurang dikuasai oleh pendidik sehingga dalam menyiapkan materi yang diajar pendidik harus melakukan persiapan mengajar yang ekstra daripada biasanya dalam pembelajaran daring.

Kedua, pendidik merasa jika pembelajaran daring kurang efektif untuk dilaksanakan. Berdasarkan hasil wawancara kepada Ibu Liza tanggal 26 Maret selaku 
pendidik pada mata pelajaran Pendidikan Agama Islam, beliau berpendapat bahwa:"Tingkat hasil belajar peserta didik selama belajar daring ini sangat menurun, hal ini dikarenakan kurang efektifnya pembelajaran secara daring yang tidak memungkinkan peserta didik untuk melakukan pembelajaran secara langsung, sehingga peserta didik tidak bisa berinteraksi dan berdiskusi secara langsung dengan teman maupun dengan kami sebagai pendidik dan kami juga tidak bisa memantau apakah peserta didik tersebut benar-benar melakukan tugasnya atau tidak".

Pembelajaran daring merupakan pembelajaran yang tidak dilakukan secara langsung atau tatap muka tapi menggunakan sistem daring (online). Hal itu menyebabkan dalam proses pelaksanaan pembelajaran daring ini ditemukan berbagai problem atau masalah yang dapat menghambat proses belajar peserta didik, salah satunya adalah pendidik terbatas dalam mengontrol berlangsungnya pembelajaran daring sehingga pendidik tidak dapat mendampingi secara langsung peserta didik dalam belajar.

Hasil observasi dan wawancara selanjutnya dengan peserta didik kelas X dan XI SMA Negeri 4 Pariaman (wawancara 5 s/d 9 April 2021),penulis juga menemukan 2 problematika yang datang dari peserta didik, yaitu:

Pertama, kurangnya motivasi belajar peserta didik. Masalah ini paling utama yang dihadapi dalam pembelajaran daring di SMA Negeri 4 Pariaman. Hal ini merupakan pengakuan dari salah seorang peserta didik yang bernama Resa peserta didik kelas XI (wawancara 7 April 2021), Resa mengatakan bahwa: "Rendahnya minat kami dalam pelajaran Pendidikan Agama Islam karena kami terbiasa santai dirumah, bermain serta membantu orang tua, dan sekarang dituntut untuk belajar dirumah, membaca materi dan mengerjakan tugas setiap pertemuan, tidak ada variasi dalam pembelajaran, menjadikan kami sangat jenuh".

Peserta didik mengalami kejenuhan saat pembelajaran daring, dikarenakan mereka belajar dari rumah sudah cukup lama yang dimulai pada pertengahan Maret 2020. Mereka juga tidak dapat bertemu dengan teman ataupun pendidik secara langsung sehingga mereka merasa malas dan bosan untuk belajar. Peserta didik dituntut mandiri dalam belajar. kadang tugas yang diberi oleh pendidik terlalu banyak, membuat peserta didik terbebani dan mengumpulkan tugas tidak tepat waktu atau terlambat bahkan juga tidak mengumpulkan. Biasanya hal ini disebabkan banyak peserta didik membiarkan tugas menumpuk sampai jadwal yang ditetapkan pendidik dan dikerjakan tergesa-gesa. Pemberian tugas ini juga tidak menjamin peserta didik akan belajar dirumah. Karena itu motivasi belajar sangat diperlukan dalam proses pembelajaran daring.

Kedua, kurangnya sarana dan prasarana peserta didik. Sesuai dengan hasil wawancara dengan salah satu peserta didik kelas X yaitu Sisca (wawancara 9 April 2021), mengatakan bahwa: "Kami tidak mempunyai paket data setiap saat, sedangkan belajar daring harus ada paket data setiap hari, kalau diminta ke orang tua kadang mereka suka marah-marah".

Proses pembelajaran daring tentu membutuhkan sarana dan prasarana berupa laptop, smartphone ataupun komputer dan bantuan jaringan internet. Jika peserta didik tidak memiliki smartphone maka bisa menjadi penghambatnya saat pembelajaran daring. Diketahui bahwa ada peserta didik yang tidak memiliki smartphone sendiri dan 
meminjam HP saudara dulu untuk dapat mengikuti sistem pembelajaran jarak jauh. Tentu hal ini menjadi problem bagi peserta didik dalam belajar dan kegiatan belajar mengajar terganggu atau tidak berjalan lancar.

\section{Upaya yang dilakukan dalam Mengatasi Problematika Pembelajaran Daring Pada Mata Pelajaran Pendidikan Agama Islam}

Pertama, pengusaan teknologi pendidik yang masih rendah. Upaya mengatasi rendahnya pemahaman teknologi pada pendidik sebenarnya pihak pendidik ataupun pihak sekolah SMA Negeri 4 Pariaman sudah melakukan beberapa upaya diantaranya dengan diadakannya bimbingan teknis dan belajar dengan pendidik yang lain yang dijadikan sebagai mentor. Hal tersebut sesuai dengan wawancara dengan Kepala Sekolah Ibu Desi, beliau mengatakan: "Dalam mengatasi kesulitan pendidik dalam penguasaan teknologi, pihak sekolah mengadakan bimbingan teknis terhadap aplikasi yang dipakai disekolah dan juga kami menyediakan beberapa mentor yang bisa membantu jika masih ada pendidik yang mengalami kesulitan" (Wawancara 23 Maret 2021).

Kedua, pendidik merasa jika pembelajaran daring kurang efektif untuk dilaksanakan. Dalam mengatasi keefektifan belajar daring bapak Mardison meyampaikan bahwa: "Kami sebagai pendidik hanya bisa memberikan waktu lebih atau tidak membatasi waktu tehadap pengerjaan tugas yang telah kami sediakan di $e$ learning"(Wawancara 22 Maret 2021).

Situasi ini membuat pendidik dituntut untuk menciptakan rancangan belajar yang simpel sperti RPP satu lembar. Hal terpenting dari rancangan pembelajaran ini yaitu kegiatan inti hanya sedikit dan tuntutan tugas yang tidak terlalu tinggi, kemudian pengumpulan tugasnya diberi batas waktu yang cukup lama dan walau singkat sudah memuat tujuan dari materi yang akan diajarkan.

Upaya yang dilakukan untuk mengatasi problematika dari peserta didik dilakukan dengan cara sebagai berikut: Pertama, kurangnya motivasi belajar peserta didik. Pemanfaatkan e-learning SMA Negeri 4 Pariaman yang dilakukan pendidik sebagai media yang bersifat konkrit dan nyata agar peserta didik memiliki motivasi terhadap mata pelajaran Pendidikan Agama Islam yanng merupakan salah satu cara yang dilakukan pendidik dan pihak sekolah dalam mengatasi bermacam-macam peserta didik Selain itu disetiap memulai pelajaran, pendidik memberikan kata-kata motivasi kepada peserta didik. Sesuai hasil wawancara dengan pendidik Pendidikan Agama Islam, mereka berpendapat: "Sebagai pendidik Pendidikan Agama Islam yang tidak hanya menyampaikan materi pelajaran, akan tetapi memberikan motivasi di dalam maupun di luar pembelajaran, setiap memulai pelajaran kami selalu mengingatkan peserta didik untuk selalu mengikuti proses pembelajaran walaupun secara daring". (Wawancara 23 s/d 26 Maret 2021)

Kedua, kurangnya sarana dan prasarana peserta didik. Kepala sekolah di SMA Negeri 4 Pariaman maupun pendidik memberikan solusi terkait peserta didik yang tidak memiliki android, yaitu dengan cara apabila ada peserta didik atau yang tidak masuk group salah seorang peserta didik memberikan informasi terkait penugasan dan bisa datang langsung dan bertanya kepada pendidik dengan datang ke sekolah karena 
pendidik di SMA Negeri 4 Pariaman standby setiap hari selama hari kerja. Solusi itu tepat karena memang ada peserta didik yang tidak mempunyai android mereka datang dan langsung bertanya kepada pendidik kelas karena berkomunikasi merupakan dasar interaksi antar manusia untuk memperoleh kesepakatan dan pemahaman yang bertujuan untuk mencapai suatu tujuan yang maksimal.

\section{Hasil yang dicapai dalam Upaya Mengatasi Problematika Pmbelajaran Daring Pada Mata Pelajaran Pendidikan Agama Islam}

Faktor pendidik di antaranya yaitu Pertama, penguasaan teknologi pendidik yang masih rendah. Untuk mengatasi pemahaman teknologi yang rendah satuan pendidikan melakukan bimbingan teknis kepada seluruh pendidik, dan berdasarkan hasil wawancara dengan Kepala Sekolah yaitu Ibu Desi Susanti, beliau berkata bahwa: "Dengan diadakannya bimbingan teknis sebanyak dua kali sebelum penggunaan $e$ learning pada saat ini, itu lumayan berhasil kepada para pendidik, yang awalnya mereka banyak yang tidak bisa lama-lama terbiasa, walau ada beberapa yang masih sulit untuk mengoperasikannya"(Wawancara 23 Maret 2021).

Kesimpulannya bahwa sudah banyak perkembangan yang memperlihatkan jika pendidik mulai terbiasa dan lihai dalam menggunakan teknologi walaupun masih ada 1 atau 2 orang pendidik yang masih gagap karena faktor umur.

Kedua, pendidik merasa jika pembelajaran daring kurang efektif untuk dilaksanakan. Upaya yang sudah dilakukan maka didapatkan hasil bahwa dengan upaya-upaya yang sudah dilakukan oleh pendidik pembelajaran daring bisa ditingkatkan keefektifan nya meski jauh lebih efektif pembelajaran secara tatap muka. Ini sesuai dengan hasil wawancara yang dilakukan dengan bapak Mardison pendidik pada mata pelajaran Pendidikan Agama Islam, beliau menyampaikan bahwa: "Dengan kami tidak membatasi waktu pengumpulan tugas perlahan-lahan peserta didik mulai mengerjakannya dan mengalami pningkatan dari sebelumnya, tetapi masih ada saja peserta didik yang mengabaikan kewajibannya"(Wawancara 24 Maret 2021).

Faktor peserta didik yaitu Pertama, kurangnya motivasi belajar peserta didik. Yang pertama yaitu dengan cara pendidik memotivasi setiap akan memulai proses pembelajaran dimulai. Tindakan tersebut berhasil memotivasi peserta didik yang sebelumnya masih setengah-setengah dalam mengikuti pelajaran walaupun masih ada beberapa yang belum termotivasi. Sesuai dengan pendapat bapak Pendi, beliau mengatakan: "Mulai banyak peserta didik yang merespon, yang sudah biasa merespon, yang biasanya acuh sudah merespon, dan ada yang masih tetap acuh, tidak mengindahkan yang telah disampaikan, dan alhamdulillah ada peningkatan walaupun masih ada yang cuek saja"(Wawancara 26 Maret 2021).

Pelaksanaan tindakan dengan layanan bimbingan kelompok, Pelaksanaan layanan bimbingan kelompok ini meningkatkan motivasi belajar daring peserta didik telah dilaksanakan dengan baik dan telah berjalan sesuai dengan tujuan.

Kedua, kurangnya sarana dan prasarana peserta didik. Berdasarkan beberapa usaha yang sudah dilakukan sekolah dan pendidik, semua masalah yang berhubungan dengan sarana dan prasarana peserta didik bisa diatasi dengan baik. Mulai dari kuota yang kurang, peserta didik yang tidak memiliki smartphone dan jaringan internet yang 
tidak ada ditempat tinggal peserta didik. Sesuai hasil wawancara dengan Kepala Sekolah Ibu Desi Susanti, beliau menyampaikan bahwa: "Dengan adanya bantuan yang diberikan kepada peserta didik berupa paket data, bagi peserta didik yang tidak mempunyai smartphone bisa menjemput tugas ke sekolah dan pada saat ujian disediakan labor untuk tetap bisa mengikuti ujian, alhamdulillah masalah teratasi, walaupun masih ada peserta didik 1 atau 2 orang disetiap kelas yang acuh saja"(Wawancara 25 Maret 2021).

\section{Simpulan}

Pelaksanaan pembelajaran daring di masa pandemi covid-19 mengalami beragam problematika yang dirasakan oleh pendidik dan peserta didik. Permasalahan dari pendidik berupa rendahnya penguasaan teknologi dan kurang efektifnya pembelajaran daring, dan dari peserta didik yaitu kurangnya motivasi peserta didik dalam belajar dan kurangnya sarana dan prasarana. Beragam permasalahan tersebut dapat diatasi dengan meningkatkan kompetensi penguasaan teknologi, meningkatkan keefektifan belajar, memotivasi peserta didik dan menyediakan sarana dan prasarana yang kurang bagi peserta didik. Hasil yang dicapai dalam upaya mengatasi masalah dari faktor pendidik dan peserta didik sudah bisa diatasi dengan upaya-upaya yang telah dilakukan oleh sekolah maupun pendidik.

\section{Referensi}

Asmuni, A. (2020). Problematika Pembelajaran Daring di Masa Pandemi Covid-19 dan $\begin{array}{lllll}\text { Solusi Pemecahannya. Jurnal Paedagogy, } 281 . & \text { 7(4), }\end{array}$ https://doi.org/10.33394/jp.v7i4.2941

Bondowoso, I. I. I. (2018). Problematika Pembelajaran Tematik Terpadu. 1(1), 45-61.

Ditjen GTK Kemendikbud. 2016. Buku Pengangan Pelatihan Instruktur Nasional/Mentor Pendidik Pembelajar. Jakarta. (n.d.).

Hanafi, Halid, D. (2018). Profesionalisme Pendidik Dalam Pengelolaan Kegiatan Pembelajaran Di Sekolah. Yogyakarta: Deepublish.

Inanna, I. (2018). Peran Pendidikan Dalam Membangun Karakter Bangsa Yang Bermoral. JEKPEND: Jurnal Ekonomi Dan Pendidikan, 1(1), 27. https://doi.org/10.26858/jekpend.v1i1.5057

Kamus Besar Bahasa Indonesia. (2007).

Kurikulum. (2002). No Title Pendidikan Agama Islam.

Mastuti, Rini, Maulana Syarif, dkk. (2020). Teaching From Home. Medan: Yayasan Kita Menulis.

Meda Yuliani, Janner Simarmata, D. (2020). Pembelajaran Daring untuk Pendidikan: Teori dan Penerapan. Medan: Yayasan Kita Menulis.

Mustofa, M. I., Chodzirin, M., Sayekti, L., \& Fauzan, R. (2019). Formulasi Model Perkuliahan Daring Sebagai Upaya Menekan Disparitas Kualitas Perguruan 
Tinggi. Walisongo Journal of Information Technology, 1(2), 151. https://doi.org/10.21580/wjit.2019.1.2.4067

Ramayulis, Nizar, S. (2009). Filsafat Pendidikan Islam: Telaah Sistem Pendidikan dan Pemikiran Para Tokohnya. Jakarta: Kalam Mulia.

Ramayulis. (2010). Ilmu Pendidikan Islam. Jakarta: Kalam Mulia.

Saputra. (2014). Pendidikan Agama Islam dan Budi Pekerti kelas VII. Jakarta: Kemendikbud.

Sigit Priatmoko, F. G. (2020). Menalar Covid-19: Ragam Gagasan Menyikapi Pandemi. Jakarta: Hanz Book.

Sugiyono. (2007). Metode Penelitian Kuantitatif Kualitatif dan R\&D. Bandung: Alfabeta.

Wibowo, W. (2011). Cara Cerdas Menulis. Jakarta: Penerbit Buku Kompas.

Wawancara dengan Kepala Sekolah Ibu Desi Susanti pada tanggal 23-25 Maret 2021

Wawancara dengan pendidik PAI Bapak Mardison pada tanggal 22-24 Maret 2021

Wawancara dengan pendidik PAI Ibu Liza Derita pada tanggal 26 Maret 2021

Wawancara dengan pendidik PAI Bapak Elpenda Pendialis pada tanggal 26 Maret 2021

Wawancara dengan peserta didik Resa 7 April 2021

Wawancara dengan peserta didik Sisca 9 April 2021 